\title{
Do bigger bats need more time to forage?
}

\author{
Esbérard, CEL. ${ }^{\mathrm{a} *}$ and Bergallo, $H G{ }^{\mathrm{b}}$

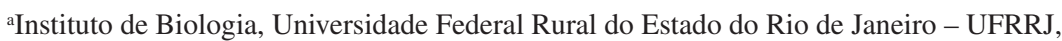 \\ Km 47 da antiga estrada Rio - São Paulo, CP 74503, CEP 23851-970, Seropédica, RJ, Brazil \\ ${ }^{\text {b} D e p a r t a m e n t o ~ d e ~ E c o l o g i a, ~ I n s t i t u t o ~ d e ~ B i o l o g i a ~ R o b e r t o ~ A l c a n t a r a ~ G o m e s ~-~ I B R A G, ~}$ \\ Universidade do Estado do Rio de Janeiro - UERJ \\ Rua São Francisco Xavier, 524, CEP 20559-900, Rio de Janeiro, RJ, Brazil \\ *e-mail: cesberard@ superig.com.br \\ Received October 10, 2006 - Accepted July 11, 2007 - Distributed November 30, 2008
}

(With 1 figure)

\begin{abstract}
We test the hypothesis is that bats using the same area and at the same time would be using similar preys, but they would have different foraging times due to specific differences in biomass. A total of 730 captures was analyzed 13 species of Vespertilionidae and Molossidae bats netted over a small dam in southeastern Brazil from 1993 and 1999. The relationship between the average time of captures and the biomass of the species of Vespertilinidae and Molossidae most frequent (captures $>4$ ) was positive and significant $(r=0.83, p=0.022, N=7)$. Two lines are discussed to answer the longer foraging time for bigger bats: 1) larger insectivorous bats don't consume proportionally larger preys and 2) larger insects are less available.
\end{abstract}

Keywords: foraging time, insectivorous bats, feeding strategies, southeastern Brazil, Molossidae, Vespertilionidae.

\section{Maiores morcegos precisam de mais tempo de forrageamento?}

\section{Resumo}

Testamos a hipótese de que morcegos insetívoros usando a mesma área podem estar usando as mesmas presas, mas têm diferentes tempos de forrageamento devido às diferenças de biomassa. De um total de 730 capturas, foram analisadas 13 espécies de Vespertilionidae e Molossidae capturadas em redes armadas sobre um pequeno açude no Sudeste do Brasil entre 1993 e 1999. A relação entre a média do horário de captura e a biomassa das espécies de Vespertilionidae e Molossidae mais freqüentes (capturas $>4)$ foi positiva e significante $(r=0,83, p=0,022, \mathrm{~N}=7)$. Duas linhas são discutidas para responder ao maior tempo de forrageamento pelos maiores morcegos: (1) morcegos insetívoros maiores não consomem presas proporcionalmente maiores; e (2) maiores insetos são menos disponíveis.

Palavras-chave: horário de forrageamento, morcegos insetívoros, estratégias alimentares, sudeste do Brasil, Molossidae, Vespertilionidae.

\section{Introduction}

Insectivorous bats have their preying activities synchronized with the activities of their prey, which maximizes success in the capture of arthropods and the saving of energy (Taylor and O'Neill, 1988). Almost all species of Microchiropteran bats studied so far have begun these activities close to sunset (Church, 1957; Herreid and Davis, 1966; Swift, 1980; Laborda and Cartwright, 1993).

A great diversity of insectivorous bats can be found over collections of water, where they capture their prey and drink (e.g. Cockrum and Cross, 1964). In an urban park, almost 13 species of Vespertilionidae and Molossidae bats were netted over a small dam (Esbérard,
2003). The high richness presented at this place, and in other samples already published elsewhere, can be explained by the minimization of interspecific competition, showing each species differences in the activity period or in the selection of prey.

Insectivorous bats are alternatively interchangeably described both as specialists and as generalists. However, most of the species are intermediate among these two extremes, being selective in some moments and opportunists in other, depending on some variables, such as the availability and abundance of prey (Laval and Laval, 1980). Choice of prey may be passive, with bats accepting the first insect detected, or active, with bats largely 
depending on prey evaluation before ingesting it (Jones and Rydell, 2003).

\section{Material and Methods}

We analyzed the capture schedule of the most frequently netted species at this park and compared it with the averaged biomass of the species. The hypothesis is that bats using the same area and at the same time would be using similar prey, but they would have different foraging times due to specific differences in biomass. We assume that larger bats would need a longer time of searching and prey assimilation than smaller bats, due to their great energetic needs (Eisenberg, 1981; Peters, 1983).

Between 1993 and 1999, 29 sampling nights were accomplished with mist nets opened over an artificial dam built in the beginning of the XX century inside an urban park of the City of Rio de Janeiro, southeastern Brazil $\left(23^{\circ} 58^{\prime} 68.7^{\prime \prime} \mathrm{S}\right.$ and $043^{\circ} 14^{\prime} 54.3^{\prime}$ 'W). This small dam (0.04 ha) is adjacent to a secondary forest. For more details of the study site see Esbérard (2003). Every night, nine or ten mist nets $(7 \times 2.5 \mathrm{~m})$ were opened for the whole night, being closed one hour after dawn. All the animals captured had their schedules of capture analyzed individually. Immediately after the capture, one of the members of the staff communicated through radio-communicator with the base, to ensure the control of the real time of capture for each bat. The moment of capture was transformed in minutes using the local time of sunset (obtained through Astronomical Ephemeredes, CNPq, Observatório Nacional), independent of the local summer time. The biomass was calculated for each species, not considering the weight of pregnant females with palpable fetuses. We used simple linear regression between the average body weight of each species and the average capture time for each species expressed in minutes after sunset. For this analysis we assume that all species begin their night activity close to sunset (Bateman and Vaughan, 1974; Erket, 1978; 1982; Avery, 1986; McAney and Fairley, 1988; Fenton et al., 1998; Kunz and Anthony, 1996).

\section{Results and Discussion}

A total of 730 captures was analyzed here, comprising 13 species: Histiotus velatus (I. Geoffroy, 1824) $(\mathrm{N}=1)$, Lasiurus blossevilli (Lesson and Garnot, 1826) ( $\mathrm{N}=1$ ), Lasiurus ega (Gervais, 1856) $(\mathrm{N}=2)$, Myotis nigricans (Schinz, 1821) ( $\mathrm{N}=49)$, Myotis ruber (E. Geoffroy, 1806) $(\mathrm{N}=1)$, Eptesicus brasiliensis (Desmarest, 1819) $(\mathrm{N}=27)$, Molossus rufus E. Geoffroy, $1805(\mathrm{~N}=2)$, Molossus molossus (Pallas, 1766) ( $\mathrm{N}=583)$, Eumops auripendulus (Schaw, 1800) $(\mathrm{N}=8)$, Cynomops abrasus (Temmincki, 1827) ( $\mathrm{N}=35)$, Nyctinomops macrotis (Gray, 1840) $(\mathrm{N}=9)$, Nyctinomops laticaudatus (E. Geoffroy, 1805) $(\mathrm{N}=2)$ and Tadarida brasiliensis (I. Geoffroy, 1824) $(\mathrm{N}=11)$, although we only used data from species represented by more than four captures.

The relationship between the average time of captures and the biomass of the species of Vespertilionidae and Molossidae bats was positive and significant ( $\mathrm{r}=0.83$, $\mathrm{p}=0.022, \mathrm{~N}=7$ ) (Figure 1).

Species of bats captured at the same place are exposed to the same fauna of insects. The consumption of different prey is a result of the detection capacity of the bat for different sizes or types of prey by the echoes that these produce (Webster, 1963; Webster and Brazier, 1968). The width of the trophic niche increases with body size for most of the species of mammals (e.g. Rosenzweigh, 1968). Essentially, greater mammals can detect, capture and consume prey both small and large, while smaller predators are restricted to the consumption of small prey. Studies of the diet of several species of neotropical bats demonstrated that several preferences

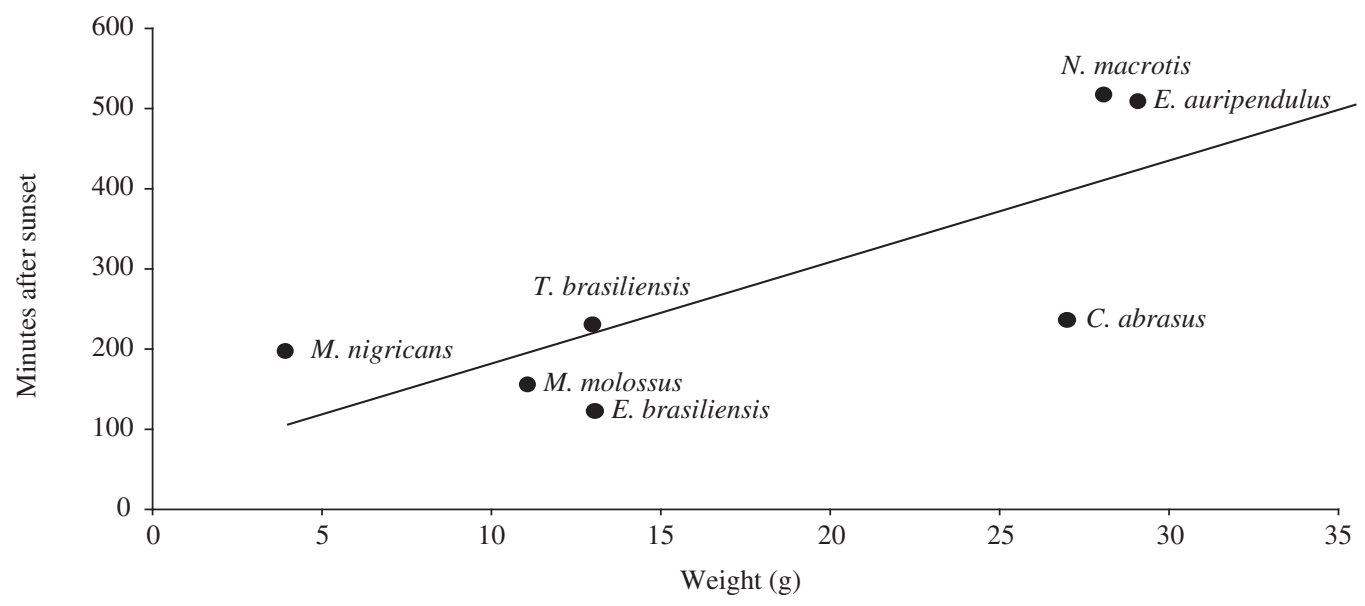

Figure 1. Variation of medium capture time (minutes after sunset) with the average weight of the species for seven of the 13 species captured. 
within orders of prey are presented, with considerable overlap (Ross, 1967; Black, 1972; Earstela and Whitaker, 1972; Howell and Burch, 1974; Freeman, 1979). Some of the work carried out on bats indicates a specialized diet, with some species preferring soft and mobile insects of similar size (Jones and Ridell, 2003).

Two lines can be adopted to answer the longer foraging time for bigger bats. Larger insectivorous bats don't consume proportionally larger prey. Bird and mammal predators of small size ingest prey that present, on average, $0.2 \%$ of its biomass, while carnivore mammals and birds can ingest prey, on average, with $10 \%$ of its biomass (Peters, 1983). Using the size of the prey already described, each species would consume at least 213 prey of $0.008 \mathrm{~g}$ (for M. nigricans) to 303 prey of $0.058 \mathrm{~g}$ (for E. auripendulus), every night to obtain the ideal amount of food. However, the optimal foraging theory is hard to accept, since the size of the prey already described for insectivorous bats varies relatively little, mainly from 5 to $10 \mathrm{~mm}$ (Gould, 1955; Ross, 1967). Otherwise, the largest species of Molossidae, Eumops perotis (Schinz, 1821) (56 g), ingests insects with only $8 \mathrm{~mm}$, while Lasiurus borealis (Müller, 1776) (11 g) captured 10 to $16 \mathrm{~mm}$ prey (Ross, 1967), suggesting that prey size was not directly related to bat biomass. Using insects proportionally smaller than the ideal for its biomass, larger bats would need a longer foraging period. Another line of thinking is that larger insects are less available. Due to the low frequency of echolocation, detection is difficult at greater distances, hindering the maneuvers, and resulting in smaller capture success and, consequently, in a greater time for the ingestion of the ideal amount (Barclay and Brigham, 1991; Kalko and Schnitzler, 1989). Seemingly the distance for detection is only $1.5 \mathrm{~m}$ for several of the species with the available time for detection being $340 \mathrm{~ms}$, restricting bigger bats that have intrinsic smaller maneuvering capacity (Barclay and Brigham, 1994). The relationship between the relative abundance of food items of different sizes and resource partitioning among potential competitors feeding on this is far from clear. If the bats used prey only proportional to their biomass, the available time for each prey would be obtained dividing the time lapse between the first and the last capture for each species with the ideal number of prey. The ideal available time for each prey varies from 2.14 minutes for $M$. nigricans to 3.46 minutes for E. auripendulus. However, this assumption would be real only if all prey sizes were equally available. Since the larger insects are rarer and more difficult to capture by larger bats, the foraging time would increase. For bats having a larger biomass, metabolic needs are also larger, and an increase of the life area or foraging time is expected to consume the ideal amount of prey.

Acknowledgements - We thank the Parque Nacional da Tijuca/ IBAMA for permission to carry out the sampling. This work was accomplished under license (Processes 1785/89-IBAMA and 4156/95-46 AC-SUPES/DF/IBAMA to C.E.L. Esbérard). During the development of this study C.E.L. Esberrard received a CNPq grant (Process 152910/2004-0) and Helena G. Bergallo received an academic productivity grant.

\section{References}

AVERY, MI. 1986. Factors affecting the emergence times of Pipistrelle bats. J. zool., vol. 209, no. 2, p. 293-296.

BATEMAN, GC. and VAUGHAN, TA. 1974. Nightly activities of mormoopid bats. J. mammal., vol. 55, no. 1, p. 45-65.

BARCLAY, RMR and BRIGHAM, RM., 1991. Prey detection, dietary niche breadth, and body size in bats: why are insectivorous bats so small?. Am. Natural., vol. 137, p. 693-703.

-, 1994. Constraints on optimal forging: a field test of prey discrimination by echolocation insectivorous bats. Anim. Behav., vol. 48, no. 6, p. 1013-1021.

BLACK, HL., 1972. Differential explotation of moths by the bats Eptesicus fuscus and Lasiurus cinereus. J. Mammal., vol. 55 , no. 1 , p. 598-601.

CATTO, CMC., PA. RACEY, and STEPHENSON, PJ., 1995. Activity patterns of the serotine bat (Eptesicus serotinus) at a roost in southern England. J. zool., vol. 235, no. 4, p. 635-644.

CHURCH, H., 1957. The time of emergence of Pipristelle. Proc. Zool. Soc. Lond., vol. 128, no. 3, p. 606-608.

EASTERLA, DA. and WHITAKER, JO., 1972. Food habits of some bats from Big Bend National Park, Texas. J. Mamm., vol. 53 , no. 3 , p. $887-890$

EISENBERG, JF., 1981. The mammalian radiations: An analysis of trends in evolution, adaption and behavior. Chicago: The University of Chicago Press. 610 p.

ERKET, HG., 1978. Sunset-related timing of flight activity in neotropical bats. Oecologica, vol. 37, no. 1, p. 59-67.

-, 1982. Ecological aspects of bat activity rgythms. In Kunz, TH. (Ed.). Ecology of bats. New York: Plenum Press. p. 201-242.

ESBÉRARD, CEL., 2003. Diversidade de morcegos em uma área de Mata Atlântica regenerada no sudeste do Brasil (Mammalia: Chiroptera). Rev. brasil. zoocienc., vol. 5, no. 2, p. $189-204$.

FENTON, M.B., RAUTENBACH, IL., RYDELL, J., ARITA, H.T., ORTEGA, J., BOUCHARD, S., HOVORKA, MD., LIM, B., ODGREN, E., PORTFORS, CV., SCULLY, WM., SYME, DM. and VONHOF, MJ., 1998. Emergence, echolocation, diet and foraging behavior of Molossus ater (Chiroptera: Molossidae). Biotropica, vol. 30, no. 2, p. 314-320.

FREEMAN, P., 1979. Specialized insectivory: Beetle-eating and moth-eating molossid bats. J. Mammal., vol. 60, no. 3, p. 467-479.

GOULD, E., 1955. The feeding efficiency of insectivorous bats. J. Mammal., vol. 36, no. 2, p. 399-407.

HERREID, CF. and DAVIS, RB., 1966. Flight patterns of bats. J. mammal., vol. 40, no. 1, p. 140-150.

HOWELL, DJ, and BURCH, D., 1974. Food habits of some Costa Rican bats. Rev. Biol. Trop., vol. 21, no. 2, p. 281-294.

JONES, G. and RYDELL, J., 2003. Attack and defense: Interactions between echolocation bats and their insect prey. In KUNZ, TH and FENTON, MB. (Eds.) Bat ecology. Chicago and London: The University of Chicago Press. p. 301-345. 
KALKO, EKV and SCHNITZLER, H-U., 1989. The echolocation and hunting behavior of Daubenton's bat, Myotis daubentoni. Behav. Ecol. Sociobiol., vol. 24, no. 1, p. 225-238.

KUNZ, TH. and ANTHONY, ELP., 1996. Variation in the timing of nightly emergence behavior in the little brown bat, Myotis lucifugus (Chiroptera: Vespertilionidae). In Contribution in mammalogy: a memorial volume honoring (Dr. J. Knox Jones, Jr. Lubbock). Texas: Museum Texas Tech University Press. p. 225-235.

LABORDA, JA. and CARTWRIGHT, A., 1993. Initial emergence factors of the big brown bat (Eptesicus fuscus). Proc. Indiana Acad. Sci., vol. 102, no. 33, p. 273-277.

LAVAL, RK and LAVAL, ML., 1980. Ecological studies and management of Missouri bats, with emphasis on cave-dwelling species. Missouri Department of Conservation, Terrestrial Series, no. 8,53 p.
McANEY, CM. and FAIRLEY. JS., 1988. Activity patterns of the lesser horseshoe bat Rhinolophus hipposideros at summer roosts. J. zool., vol. 216, no. 22, p. 325-338.

PETERS, RH. 1983. The ecological implications of body size. Cambridge: The Cambridge University Press. 329 p.

ROSS, A., 1967. Ecological aspects of the food habits of insectivorous bats. Proc. West. Found. Vert. Zool., vol. 1, no. 2, p. 205-263.

SWIFT, SM., 1980. Activity patterns of Pipistrelle bats (Pipistrellus pipistrellus) in north-east Scotland. J. Zool. vol. 190 , no. 2 , p. 285-295.

TAYLOR, RJ and O’NEILL., MG. 1988. Summer activity patterns of insectivorous bats and their prey in Tasmania. Aust. Wildl. Res. vol. 15, no. 4, p. 533-539. 